\title{
FAKTOR-FAKTOR YANG MEMPENGARUHI MUTU PELAYANAN KESEHATAN PADA PASIEN PENDERITA HIPERTENSI DI PUSKESMAS RANTANG MEDAN PETISAH TAHUN 2019
}

\author{
FITRI HUTAGALUNG ${ }^{1}$, HERBERT WAU ${ }^{2}$ \\ UNIVERSITAS PRIMA INDONESIA, MEDAN, INDONESIA \\ JIn. Sekip Simp Sikambing - Medan Sumatera Utara \\ fitrihutagalung1997@gmail.com
}

DOI : https://doi.org/10.35451/jkf.v2i1.197

\begin{abstract}
Rantang Medan Petisah Health Center is a non-inpatient health center. Health service quality can be interpreted as a health service that can satisfy every user of the service in accordance with the level of satisfaction of the average population, and its implementation in accordance with the standards of the established professional code of ethics. Satisfaction with health services seen from the quality of health services $53.5 \%$ of respondents who were dissatisfied with the health services provided, such as inadequate facilities and infrastructure, namely the condition of the waiting room which was considered narrow and uncomfortable, inadequate parking facilities, administrative processes which is considered slow, lacks the friendliness of health workers in serving patients' needs. The design of this study was descriptive analytic with Cross Sectional design. The total population of the study was 61 people with the sampling technique was purposive sampling. Retrieving data using a questionnaire measuring instrument. Data analysis was univariate and bivariate (Chi-Square Test) with $p$-value $=0.05$. The results showed that physical evidence with a $p$ value of $0.015<0.05$, reliability with a $p$ value of $0.000<0.05$, and responsiveness with a $p$ value of $0.001<0.05$. The conclusion of this study is that physical evidence, reliability, and responsiveness have a significant influence on the quality of health services. It is recommended to the health center to improve the comfort of the waiting room and parking facilities, and administrative officers are expected to improve timeliness in serving the needs of patients.
\end{abstract}

Keywords: Quality of Service, Physical Evidence, Reliability, Responsiveness

\section{Pendahuluan}

Undang-Undang Kesehatan No. 36 Tahun 2009 menegaskan bahwa setiap orang mempunyai hak yang sama dalam memperoleh akses atas sumber daya di bidang kesehatan dan memperoleh kesehatan. Setiap orang mempunyai hak dalam memperoleh pelayanan kesehatan yang aman, bermutu dan terjangkau (1).
Salah satu fasilitas kesehatan yang banyak dimanfaatkan masyarakat adalah puskesmas yang merupakan sarana pelayanan kesehatan strata pertama dalam pemberian pelayanan kesehatan kepada masyarakat yang mempunyai peranan penting dalam mewujudkan derajat kesehatan masyarakat, mengoptimalisasikan dan mengintegrasikan semua upaya 
keperawatan kesehatan di Puskesmas agar pelayanan yang diberikan bermutu, holistik dan komprehensif (2).

Indonesia Service Dialog (ISD) mencatat jumlah orang Indonesia yang berobat ke luar negeri mengalami peningkatan hamper $100 \%$ yaitu tahun 2006 terdapat 350 ribu orang pasien, tahun 2015 melonjak menjadi 600 ribu pasien. Alasan yang menyebabkan pasien berobat ke luar negeri yaitu pasien banyak melakukan perbandingan kualitas pelayanan kesehatan di Indonesia dan luar negeri misalnya, kualitas mutu pelayanan, keamanan, kebersihan, dan pengawasan dalam pelayanan kesehatan luar negeri dianggap lebih baik. Teknologi dalam pelayanan kesehatan di luar negeri dianggap lebih canggih, pengalaman salah diagnosis oleh dokter di Indonesia yang kerap dialami pasien, teknologi yang digunakan dalam pelayanan kesehatan di luar negeri dianggap lebih canggih, terbatasnya waktu dokter di Indonesia untuk memeriksa keluhan pasien(3).

Data Legatum Prosperity Index (2017) menempatkan Luxemburg di peringkat 1 dari 149 negara dan Singapura di peringkat 2 dari 149 negara yang memiliki sistem kesehatan terbaik di dunia. Hal ini disebabkan karena negara-negara maju memiliki layanan kesehatan yang baik dan ditunjang infrastruktur memadai. Indeks kesehatan global Indonesia berada di peringkat 101 dari 149 negara, dapat disimpulkan bahwa Indonesia berada dalam posisi yang buruk dibandingkan negara lain. Hal ini disebabkan karena dari sisi pengobatan dan infrastruktur kesehatan, masih banyak wilayah terpencil yang masih sulit untuk mengakses layanan medis, bahkan wilayah yang sudah memiliki layanan medis lengkap pun, belum tentu mendapatkan layanan kesehatan karena biaya yang mahal(4).

Berdasarkan data WHO pada tahun 2013 prevalensi Hipertensi tertinggi terjadi di wilayah Afrika yaitu sebesar $46 \%$ orang dewasa, dan prevalensi terendah terdapat di wilayah Amerika yaitu sebesar $35 \%$ orang dewasa(5).

Hasil RISKESDAS (2018), menyatakan prevalensi hipertensi di Indonesia pada umur $\geq 18$ tahun sebesar $8,4 \%$, dan Sumatera Utara sebesar 4,5\%. Hal ini menandakan bahwa penyakit hipertensi belum mendapat perhatian lebih dari masyarakat(6).

Beberapa tahun terakhir ini angka kesakitan dan kematian di Indonesia diakibatkan oleh penyakit tidak menular, salah satunya adalah hipertensi. Hipertensi seringkali tidak bergejala, sehingga tidak mendapat perhatian dan akhirnya berakibat pada komplikasi berat, seperti jantung, stroke, dan gagal ginjal. Untuk mengurangi angka kesakitan dan kematian tersebut maka pasien penderita hipertensi diharuskan untuk melakukan pengobatan secara teratur, agar tidak sampai pada komplikasi. Untuk itu perlu adanya upaya tindakan preventif atas penyakit hipertensi.

\section{Data Dinas Kesehatan Kota} Medan (2016), menyatakan bahwa pada tahun 2012 sampai tahun 2016 penyakit ISPA dan Hipertensi menjadi penyakit terbanyak pada pasien rawat jalan di Puskesmas Kota Medan. Pada tahun 2012 ISPA sebanyak 47,5\% dan Hipertensi sebanyak 9,8\%, tahun 2013 ISPA sebanyak $38,4 \%$ dan Hipertensi sebanyak $11,2 \%$, tahun 2014 ISPA sebanyak $46,1 \%$ dan Hipertensi sebanyak $12,0 \%$, tahun 2015 ISPA sebanyak $39,87 \%$ dan Hipertensi sebanyak 14,51\%, tahun 2016 ISPA sebanyak 40,23\% dan Hipertensi sebanyak $16,63 \%(7)$. 
Masyarakat menginginkan suatu pelayanan yang sesuai dengan harapan mereka. Mutu pelayanan kesehatan sebagai salah satu bagian dari manajemen akan memberikan berbagai manfaat bagi manajemen suatu instansi. Oleh karena itu, setiap pemberi layanan kesehatan atau profesi layanan kesehatan yang secara langsung melayani pasien perlu memiliki keterampilan, termasuk dalam berkomunikasi dengan konsumen/pasien. Meski demikian mutu pelayanan kesehatan tidak hanya ditentukan dari tingkat kemampuan akademisnya, tetapi juga oleh sifatsifat kemanusiaan yang dimiliki oleh petugas kesehatan disuatu rumah sakit maupun di puskesmas (8).

Azwar (1996), menyatakan pelayanan kesehatan yang bermutu adalah pelayanan kesehatan yang dapat memuaskan setiap pemakai jasa pelayanan sesuai dengan tingkat kepuasan rata-rata penduduk, serta penyelenggaraannya sesuai dengan standar kode etik profesi yang ditetapkan. Selain itu faktor utama dalam pelayanan kesehatan yang menentukan kepuasan selain mutu hasil mengatasi masalah kesehatan yaitu adanya kesembuhan, juga mutu pelayanan petugas yang baik, ramah, santun dan kelengkapan sarana(9).

Puskesmas Rantang Kecamatan Medan Petisah memiliki pelayanan yang terdiri dari ruang administrasi/rekam medik, ruang pemeriksaan dewasa umur $18-<60$ tahun, ruang pemeriksaan dewasa umur $>60$ tahun, ruang pemeriksaan gigi, ruang pemeriksaan anak (umur $0-<18$ tahun), ruang pemeriksaan $\mathrm{KIA} / \mathrm{KB} / \mathrm{gizi}$, ruang pemeriksaan TBDOTS/TB-MDR, ruang pemeriksaan laboratorium, ruang farmasi dan gudang obat(10).

$\begin{array}{ccc}\text { Hasil penelitian Astawa di } \\ \text { Puskesmas } & \text { Rumbia Kabupaten }\end{array}$

Lampung Tengah pada tahun 2012 tentang mutu pelayanan kesehatan sangat dipengaruhi oleh dimensi mutu, bahwa terdapat $73 \%$ pasien di Puskesmas Rumbia yang mengeluh terhadap mutu pelayanan. Terdapat 56\% keterjangkauan. Dimensi kenyamanan $42 \%$ menilai baik dan $58 \%$ menilai tidak baik. Sedangkan dimensi ketepatan waktu $48 \%$ yang menilai baik dan $52 \%$ yang menilai tidak baik(11).

Berdasarakan

survey pendahuluan yang diperoleh peneliti di Puskesmas Rantang selama tiga tahun terakhir yaitu tahun 2015 sebanyak 2.210 jiwa, tahun 2016 sebanyak 3.597 jiwa dan tahun 2017 sebanyak 3.259 jiwa. Peningkatan kunjungan pasien dikarenakan pasien yang berobat ke Puskesmas Rantang mendapat pengobatan gratis dengan menggunakan BPJS, jarak antara rumah dengan tempat pelayanan kesehatan lebih dekat sehingga memudahkan untuk berobat(12-14).

Hasil wawancara terhadap 10 orang pasien ditemukan permasalahan yang mengakibatkan mutu pelayanan di Puskesmas Rantang tersebut masih belum sesuai dengan harapan pasien, dimana pasien mengharapkan petugas kesehatan cepat tanggap dalam melayani kebutuhan pasien.Kemudian ditemukan juga permasalahan lain dimana ketika pasien penderita hipertensi datang ke Puskesmas Rantang untuk mengambil obat namun obat yang tersedia di puskesmas tersebut habis. Hal ini menyebabkan pasien mengeluarkan biaya untuk membeli obat di apotek. Fasilitas ruang tunggu yang dinilai tidak nyaman dan sempit menyebabkan pasien tidak mendapatkan tempat duduk ketika menunggu proses administrasi hingga proses pemeriksaan selesai, kondisi fasilitas parkir yang tidak memadai, ketepatan petugas dalam melakukan 
administrasi dinilai kurang baik, sikap petugas dalam melayani pasien kurang ramah. Tujuan penelitian ini adalah untuk mengetahui Faktor-Faktor yang Mempengaruhi Mutu Pelayanan Kesehatan pada Pasien Penderita Hipertensi di Puskesmas Rantang Medan Petisah Tahun 2019.

\section{METODOLOGI PENELITIAN}

Penelitian ini merupakan jenis penelitian yang menggunakan metode survei analitik yang bertujuan mengetahui faktor-faktor yang mempengaruhi mutu pelayanan kesehatan pada pasien penderita hipertensi di Puskesmas Rantang Medan Petisah tahun 2019. Rancangan Penelitian yang digunakan dalam penelitian ini adalah ini adalah cross sectiona(15)l.

Populasi dalam penelitian ini adalah pasien penderita hipertensi dengan jumlah kunjungan pada bulan Desember tahun 2017 sebanyak 158 orang di Puskesmas Rantang Medan Petisah. Sampel dalam penelitian ini adalah sebagian dari populasi. Sampel yang diambil sebanyak 4 orang dengan perhitungan besar sampel menggunakan rumus Sugiyono (2017). Pemilihan sampelnya dengan teknik Purpossive Sampling(16).

$$
\begin{gathered}
n=\frac{\mathrm{N}}{1+\mathrm{N}\left(\alpha^{2}\right)} \\
n=\frac{158}{1+158\left(0,1^{2}\right)} \quad n=\frac{158}{2,58} \quad n=61
\end{gathered}
$$

Keterangan: $\mathrm{N}=$ Besar Populasi

$$
\begin{aligned}
& \mathrm{n}=\text { Besar Sampel } \\
& \mathrm{a}=\text { tingkat kepercayaan }
\end{aligned}
$$

yang diinginkan (90\%)

Penelitian ini dilakukan pada bulan Juni 2019. Pengumpulan data dalam penelitian dilakukan dengan wawancara dengan menggunakan alat bantu kuesioner. Uji Satistik pada analisis data menggunakan $\mathrm{Uji}$ Chi Square $\left(\mathrm{X}^{2}\right)$ dengan tingkat kepercayaan 95\% menggunakan program SPSS versi 16.0.

\section{HASIL PENELITIAN \\ Analisis Univariat \\ Distribusi Frekuensi Responden}

Berdasarkan tabel 1 dibawah, dapat diketahui bahwa jumlah responden berdasarkan karakteristik Jenis Kelamin, mayoritas responden berjenis kelamin laki-laki berjumlah 37 $(60,7 \%)$, dan minoritas responden berjenis kelamin perempuan berjumlah $24(39,3 \%)$, distribusi berdasarkan umur, mayoritas responden berumur 46-53 tahun berjumlah 28 orang $(45,9)$, dan minoritas responden berumur 30-37 berjumlah 1 orang $(1,6 \%)$, distribusi berdasarkan lama perawatan, mayoritas responden lama perawatan $5-8$ bulan berjumlah 26 orang $(42,6 \%)$, minoritas responden lama perawatan 9-12 bulan berjumlah 16 orang $(26,2 \%)$, distribusi berdasarkan pendidikan, mayoritas responden berpendidikan SMA berjumlah $44 \quad(72,1 \%)$, minoritas responden berpendidikan Sarjana berjumlah $1(1,6 \%)$, dan distribusi berdasarkan pekerjaan, mayoritas responden bekerja sebagai wiraswasta berjumlah 28 (45,9\%), minoritas responden bekerja sebagai PNS dan Pensiunan berjumlah $1(1,6 \%)$.

Tabel 1

Distribusi Frekuensi Responden

\begin{tabular}{ccc}
\hline $\begin{array}{c}\text { Jenis } \\
\text { Kelamin }\end{array}$ & $\begin{array}{c}\text { Frekue } \\
\text { nsi (n) }\end{array}$ & $\begin{array}{c}\text { Present } \\
\text { ase (\%) }\end{array}$ \\
\hline $\begin{array}{c}\text { Laki-Laki } \\
\text { Perempu } \\
\text { an }\end{array}$ & 37 & 60,7 \\
\hline Total & $\mathbf{6 1}$ & $\mathbf{1 0 0}$ \\
\hline Umur & & \\
\hline $30-37$ & 1 & 1,6 \\
$38-45$ & 19 & 31,1 \\
$46-53$ & 28 & 45,9 \\
$54-62$ & 13 & 21,3 \\
\hline Total & $\mathbf{6 1}$ & $\mathbf{1 0 0}$ \\
\hline
\end{tabular}


Received: 27 Agustus 2019 :: Accepted: 29 Agustus 2019:: Published: 31 Oktober 2019

\begin{tabular}{|c|c|c|}
\hline $\begin{array}{c}\text { Lama } \\
\text { Perawat } \\
\text { an }\end{array}$ & & \\
\hline $1-4 \mathrm{bln}$ & 19 & 31,1 \\
\hline 5-8bln & 26 & 42,6 \\
\hline $9-12$ & 16 & 26,2 \\
\hline Total & 61 & 100 \\
\hline \multicolumn{3}{|l|}{$\begin{array}{c}\text { Pendidi } \\
\text { kan }\end{array}$} \\
\hline SMP & 5 & 8,2 \\
\hline SMA & 44 & 72,1 \\
\hline Akademi & 11 & 18,0 \\
\hline Sarjana & 1 & 1,6 \\
\hline Total & 61 & 100 \\
\hline \multicolumn{3}{|l|}{$\begin{array}{c}\text { Pekerja } \\
\text { an }\end{array}$} \\
\hline $\begin{array}{l}\text { Tidak } \\
\text { Bekerja }\end{array}$ & 16 & 26,2 \\
\hline PNS & 1 & 1,6 \\
\hline $\begin{array}{l}\text { Wiraswa } \\
\text { sta }\end{array}$ & 28 & 45,9 \\
\hline $\begin{array}{l}\text { Pegawai } \\
\text { Swasta }\end{array}$ & 15 & 24,6 \\
\hline $\begin{array}{c}\text { Pensiuna } \\
\mathrm{n}\end{array}$ & 1 & 1,6 \\
\hline Total & 61 & 100 \\
\hline
\end{tabular}

\section{Distribusi Frekuensi Berdasarkan Variabel Bebas Penelitian}

Berdasarkan tabel 2 dibawah dapat dilihat bahwa berdasarkan bukti fisik, mayoritas responden adalah dengan kategori tidak baik sebanyak 39 orang $(63,9 \%)$ dan minoritas responden adalah dengan kategori baik sebanyak 22 orang (36,1\%). Berdasarkan kehandalan, mayoritas responden adalah dengan kategori tidak baik sebanyak 34 orang $(55,7 \%)$ dan minoritas responden adalah dengan kategori baik sebanyak 27 orang (44,3\%). Berdasarkan daya tanggap, mayoritas responden adalah dengan kategori tidak baik sebanyak 40 orang $(65,6 \%)$ dan minoritas responden adalah dengan kategori baik

sebanyak 21 orang (34,4\%). Berdasarkan Empati, mayoritas responden adalah dengan kategori tidak baik sebanyak 33 orang $(54,1 \%)$ dan minoritas responden adalah dengan kategori baik sebanyak 28 orang $(45,9 \%)$. Berdasarkan Jaminan, mayoritas responden adalah dengan kategori baik sebanyak 43 orang $(70,5 \%)$ dan minoritas responden adalah dengan kategori tidak baik sebanyak 18 orang $(29,5 \%)$.

Tabel 2

Distribusi Frekuensi Berdasarkan Variabel Bebas Penelitian Variabel Frekuens Persentas

\begin{tabular}{|c|c|c|}
\hline & $i(n)$ & e $(\%)$ \\
\hline \multicolumn{3}{|l|}{ Bukti Fisik } \\
\hline Baik & 22 & 36,1 \\
\hline Tidak Baik & 39 & 63,9 \\
\hline Total & 61 & 100,0 \\
\hline \multicolumn{3}{|l|}{ Kehandala } \\
\hline $\mathbf{n}$ & 27 & 44,3 \\
\hline Baik & 34 & 55,7 \\
\hline \multicolumn{3}{|l|}{ Tidak Baik } \\
\hline Total & 61 & 100,0 \\
\hline \multicolumn{3}{|l|}{ Daya } \\
\hline Tanggap & 21 & 34,4 \\
\hline Baik & 40 & 65,6 \\
\hline \multicolumn{3}{|l|}{ Tidak Baik } \\
\hline Total & 61 & 100,0 \\
\hline \multicolumn{3}{|l|}{ Empati } \\
\hline Baik & 28 & 45,9 \\
\hline Tidak Baik & 33 & 54,1 \\
\hline Total & 61 & 100,0 \\
\hline \multicolumn{3}{|l|}{ Jaminan } \\
\hline Baik & 43 & 70,5 \\
\hline Tidak Baik & 18 & 29,5 \\
\hline Total & 61 & 100,0 \\
\hline
\end{tabular}

\section{Analisis Bivariat}

Hasil analisi bivariat dengan menggunakan Uji Chi-Square diperoleh nilai $p$ value $=0,015$ ( $p$ value $<0,05)$, artinya Ha diterima dan Ho ditolak, yang artinya ada pengaruh yang signifikan antara bukti fisik dengan mutu pelayanan kesehatan di Puskesmas Rantang Medan Petisah 
Tahun 2019. Hasil analisi bivariat dengan menggunakan Uji Chi-Square diperoleh nilai $p$ value $=0,000(p$ value $<0,05)$, artinya Ha diterima dan Ho ditolak, yang artinya ada pengaruh yang signifikan antara kehandalan dengan mutu pelayanan kesehatan di Puskesmas Rantang Medan Petisah Tahun 2019. Hasil analisi bivariat dengan menggunakan Uji Chi-Square diperoleh nilai $p$ value $=0,001(p$ value $<0,05)$, artinya Ha diterima dan Ho ditolak, yang artinya ada pengaruh yang signifikan antara daya tanggap dengan mutu pelayanan kesehatan di Puskesmas Rantang Medan Petisah Tahun 2019. Hasil analisi bivariat dengan menggunakan Uji Chi-Square diperoleh nilai $p$ value $=0,500(p$ value $>0,05)$, artinya Ho diterima dan $\mathrm{Ha}$ ditolak, yang artinya tidak ada pengaruh yang signifikan antara empati dengan mutu pelayanan kesehatan di Puskesmas Rantang Medan Petisah Tahun 2019. Hasil analisi bivariat dengan menggunakan Uji Chi-Square diperoleh nilai $p$ value $=0,804(p$ value $>0,05)$, artinya Ho diterima dan $\mathrm{Ha}$ ditolak, yang artinya tidak ada pengaruh yang signifikan antara jaminan dengan mutu pelayanan kesehatan di Puskesmas Rantang Medan Petisah Tahun 2019.

Tabel 3

Pengaruh Variabel Bebas dengan Mutu Pelayanan Kesehatan

\begin{tabular}{|c|c|c|c|c|c|c|c|}
\hline \multirow{4}{*}{ Variabe } & \multicolumn{4}{|c|}{ Mutu Pelayanan Kesehatan } & \multirow{3}{*}{$\mathbf{n}$} & \multirow{3}{*}{$\%$} & \multirow{3}{*}{$\begin{array}{c}p \\
\text { Val } \\
\text { ue }\end{array}$} \\
\hline & & & & & & & \\
\hline & \multicolumn{2}{|c|}{ Puas } & \multicolumn{2}{|c|}{ Tidak Puas } & & & \\
\hline & $\mathbf{N}$ & $\%$ & $\mathbf{n}$ & $\%$ & & & \\
\hline \multicolumn{8}{|l|}{ Bukti Fisik } \\
\hline Baik & 15 & 68,2 & 7 & 31,8 & 22 & 100 & 0,01 \\
\hline Tidak Baik & 14 & 35,9 & 25 & 64,1 & 39 & 100 & 5 \\
\hline \multicolumn{8}{|l|}{ Kehandala } \\
\hline Baik & 20 & 74,1 & 7 & 25,9 & 27 & 100 & 0,00 \\
\hline Tidak Baik & 9 & 26,5 & 25 & 73,5 & 34 & 100 & 0 \\
\hline \multicolumn{8}{|l|}{ Daya Tang } \\
\hline Baik & 16 & 76,2 & 5 & 23,8 & 21 & 100 & 0,00 \\
\hline Tidak Baik & 13 & 32,5 & 27 & 67,5 & 40 & 100 & 1 \\
\hline \multicolumn{8}{|l|}{ Empati } \\
\hline Baik & 12 & 42,9 & 16 & 57,1 & 28 & 100 & \multirow{2}{*}{0,50} \\
\hline Tidak Baik & 17 & 51,5 & 16 & 48,5 & 33 & 100 & \\
\hline \multicolumn{8}{|l|}{ Jaminan } \\
\hline Baik & 20 & 46,5 & 23 & 53,5 & 43 & 100 & 0,80 \\
\hline Tidak Baik & 9 & 50,0 & 9 & 50,0 & 18 & 100 & 4 \\
\hline
\end{tabular}

4.
4. PEMBAHASAN

Pengaruh Bukti Fisik dengan Mutu Pelayanan Kesehatan di Puskesmas Rantang Medan Petisah Tahun 2019

Berdasarkan hasil penelitian dengan menggunakan uji Chi-Square Test dapat diketahui dari hasil uji statistik diperoleh nilai $\mathrm{p}$ value $=0,015$, maka dapat disimpulkan bahwa ada pengaruh antara bukti fisik dengan mutu pelayanan kesehatan di Puskesmas Rantang Medan Petisah Tahun 2019.

Hal ini sejalan dengan penelitian di Kabupaten Sragen, dengan judul Pengaruh Mutu Pelayanan Kesehatan dengan Tingkat Kepuasan Pasien Rawat Jalan Peserta Jaminan Kesehatan Nasional di Wilayah Kerja Puskesmas Ngrampel. Dari 100 responden diperoleh nilai $p$-value $=0,049$ nilai $p<$ 0,05. Maka Ho ditolak dan Ha diterima, artinya bukti fisik berpengaruh positif dan signifikan terhadap kepuasan pasien (17).

Menurut asumsi peneliti, dari 22 responden yang menjawab baik bukti fisik dalam mutu pelayanan yang diberikan, mayoritas responden merasa puas sebanyak 15 orang $(68,2 \%)$. Hal ini berarti responden merasa puas akan kenyamanan berobat di Puskesmas Rantang Medan Petisah.

Dari 22 responden yang menjawab baik bukti fisik dalam mutu pelayanan yang diberikan, minoritas responden menjawab tidak puas sebanyak 7 orang $(31,8 \%)$, artinya responden tidak puas akan kenyamanan berobat di Puskesmas Rantang Medan Petisah dikarenakan kondisi ruang tunggu dan fasilitas parkir di Puskesmas tersebut dinilai kurang nyaman.

Sedangkan 39 responden yang bukti fisik pelayanan kesehatan nya tidak baik, mayoritas responden menjawab tidak puas sebanyak 25 
orang $(64,1 \%)$ dan minoritas responden menjawab puas sebanyak 14 orang $(35,9 \%)$. Hal ini dapat dirasakan dan dilihat secara langsung oleh responden dengan merasakan pelayanan dari fasilitas fisik dan sarana perlengkapan yang memadai di Puskesmas Rantang Medan Petisah.

Hasil ini menguatkan teori Parasuraman, Zeithml dan Berry dalam Lidiana, (2017), Mutu pelayanan kesehatan dapat dirasakan langsung oleh penggunanya dengan menyediakan saranan dan prasarana yang memadai. Tenaga kesehatan akan mampu bekerja secara optimal sesuai keterampilannya masing-masing(17).

\section{Pengaruh Kehandalan dengan Mutu Pelayanan Kesehatan di Puskesmas Rantang Medan Petisah Tahun 2019}

Berdasarkan Uji Chi-Square diperoleh nilai $p$ value $=0,000(p$ value $<0,05)$, artinya Ha diterima dan Ho ditolak, yang artinya ada pengaruh yang signifikan antara kehandalan dengan mutu pelayanan kesehatan di Puskesmas Rantang Medan Petisah Tahun 2019.

Penelitian ini sejalan dengan penelitian di Sragen, dengan judul Kualitas Pelayanan Kepuasan Pasien Rumah Sakit Sarila Husada. Dari 100 responden pasien rawat jalan diperoleh nilai $p$-value $=, 004$ nilai $p<0,05$. Maka kehandalan mempunyai pengaruh posistif dan signifikan terhadap epuasan pasien rumah sakit Sarila Husada Sragen pada pasien rawat jalan (18).

Penelitian ini juga sejalan dengan penelitian di Kabupaten Sragen, dengan judul Pengaruh Mutu Pelayanan Kesehatan dengan Tingkat Kepuasan Pasien Rawat Jalan Peserta Jaminan Kesehatan Nasional di Wilayah Kerja Puskesmas Ngrampel. Dari 100 responden diperoleh nilai $p$ value $=0,038$ nilai $\mathrm{p}<0,05$. Maka Ho ditolak dan $\mathrm{Ha}$ diterima, artinya kehandalan berpengaruh positif dan signifikan terhadap kepuasan pasien (17).

Menurut asumsi peneliti diketahui bahwa dari 27 responden yang kehandalan dalam pelayanan kesehatan nya baik, mayoritas responden menjawab puas sebanyak 20 orang $(74,1 \%)$ dan minoritas responden menjawab tidak puas sebanyak 7 orang $(25,9 \%)$. Hal ini berarti responden merasa puas akan ketepatan waktu pelayanan di Puskesmas Rantang.

Dari 34 responden yang kehandalan dalam pelayanan kesehatan nya tidak baik, mayoritas responden menjawab tidak puas sebanyak 25 orang $(73,5 \%)$ dan minoritas responden menjawab puas sebanyak 9 orang (26,5\%). Maka kehandalan dan mutu pelayanan kesehatan memiliki hubungan sebab akibat satu sama lain. Kehandalan berkaitan dengan kemampuan tenaga kesehatan dalam memberikan pelayanan kesehatan secara tepat dan akurat dapat menjadi hal positif terhadap mutu pelayanan kesehatan di Puskesmas Rantang Medan Petisah, sehingga pasien yang datang berobat mempunyai kepercayaan terhadap pelayanan puskesmas.

$\mathrm{Hal}$ ini menguatkan teori Parasuraman Zeithml (2018), kehandalan merupakan kemampuan untuk memberikan pelayanan sesuai dengan janji yang ditawarkan. Penilaian mutu pelayanan dilihat dari kemampuan tenaga kesehatan yang berkaitan dengan ketepatan waktu pelayanan, pendaftaran, waktu pengobatan/pemeriksaan, kesesuaian antara harapan dan realisasi waktu bagi pasien.

\section{Pengaruh Daya Tanggap dengan} Mutu Pelayanan Kesehatan di 
Received: 27 Agustus 2019 :: Accepted: 29 Agustus 2019:: Published: 31 Oktober 2019

Puskesmas Rantang Medan Petisah Tahun 2019

Berdasarkan Uji Chi-Square diperoleh nilai $p$ value $=0,001(p$ value $<0,05)$, artinya Ha diterima dan Ho ditolak, yang artinya ada pengaruh yang signifikan antara daya tanggap dengan mutu pelayanan kesehatan di Puskesmas Rantang Medan Petisah Tahun 2019.

Penelitian ini sejalan dengan penelitian yang dilaukan oleh Boy Susanto (2011) tentang Pengaruh Kualitas Jasa Pelayanan Terhadap Kepuasan Pasien Pada Rumah Sakit Umum Kota Banjar yaitu terdapat pengaruh daya tanggap dengan mutu pelayanan kesehatan (19).

Hal ini tidak sejalan dengan penelitian di Kabupaten Sragen, dengan judul Pengaruh Mutu Pelayanan Kesehatan dengan Tingkat Kepuasan Pasien Rawat Jalan Peserta Jaminan Kesehatan Nasional di Wilayah Kerja Puskesmas Ngrampel. Dari 100 responden diperoleh nilai $p$ value $=0,568$ nilai $\mathrm{p}>0,05$. Maka Ho diterima dan $\mathrm{Ha}$ ditolak, artinya daya tanggap tidak berpengaruh signifikan terhadap kepuasan pasien. Artinya tinggi rendahnya daya tanggap yang ditawarkan puskesmas tidak akan mempengaruhi kepuasan pasien (17).

Menurut asumsi peneliti bahwa dari 21 responden yang daya tanggap dalam pelayanan kesehatan nya baik, mayoritas responden menjawab puas sebanyak 16 orang $(76,2 \%)$ dan minoritas responden menjawab tidak puas sebanyak 5 orang $(23,8 \%)$. Hal ini berarti responden merasa puas akan kecepatan tindakan petugas kesehatan dalam melayani kebutuhan pasien.

Dari 40 responden yang daya tanggap dalam pelayanan kesehatan nya tidak baik, mayoritas responden menjawab tidak puas sebanyak 27 orang $(67,5 \%)$ dan minoritas responden menjawab puas sebanyak
13 orang $(32,5 \%)$. Dimana responden kurang puas akan ketepatan tindakan tenaga kesehatan dalam melayani kebutuhan pasien. Hal ini dapat dilihat dari jawaban responden yang merasa tidak puas terhadap proses pendaftaran yang dinilai sering menunggu lama. Artinya, daya tanggap juga menjadi hal yang perlu ditingkatkan oleh Puskesmas Rantang Medan Petisah agar tenaga kesehatan lebih cepat dalam menangani kebutuhan pasien dan lebih cepat dalam menyelasaikan pekerjaan.

Hal ini menguatkan teori Parasuraman Zeithml (2018), daya tanggap merupakan respon atau kesigapan dalam memberikan pelayanan yang cepat dan tanggap yang meliputi kecepatan petugas kesehatan dalam menangani kebutuhan pasien.

\section{Pengaruh Empati dengan Mutu Pelayanan Kesehatan di Puskesmas Rantang Medan Petisah Tahun 2019}

Berdasarkan Uji Chi-Square diperoleh nilai $p$ value $=0,500(p$ value $>0,05)$, artinya Ho diterima dan $\mathrm{Ha}$ ditolak, yang artinya tidak ada pengaruh yang signifikan antara empati dengan mutu pelayanan kesehatan di Puskesmas Rantang Medan Petisah Tahun 2019.

Penelitian ini sejalan dengan penelitian di Sragen, dengan judul Kualitas Pelayanan Kepuasan Pasien Rumah Sakit Sarila Husada. Dari 100 responden pasien rawat jalan diperoleh nilai $p$-value $=0,091$ nilai $p>0,05$. Maka empati tidak mempunyai pengaruh posistif dan signifikan terhadap kepuasan pasien rumah sakit Sarila Husada Sragen pada pasien rawat jalan. Hal ini dapat diartikan jika kemudahan untuk memberikan keterangan dan perhatian kepada pasien dengan baik belum tentu meningkat (18). 
Penelitian ini tidak sejalan dengan penelitian di Kabupaten Sragen, dengan judul Pengaruh Mutu Pelayanan Kesehatan dengan Tingkat Kepuasan Pasien Rawat Jalan Peserta Jaminan Kesehatan Nasional di Wilayah Kerja Puskesmas Ngrampel. Dari 100 responden diperoleh nilai $p$ value $=0,001$ nilai $\mathrm{p}<0,05$. Maka Ho ditolak dan Ha diterima, artinya empati berpengaruh positif dan signifikan terhadap kepuasan pasien (17).

Menurut asumsi peneliti diketahui bahwa dari 28 responden yang empati dalam pelayanan kesehatan nya baik, mayoritas responden menjawab tidak puas sebanyak 16 orang 57,1\%) dan minoritas responden menjawab puas sebanyak 12 orang (42,9\%). Hal ini berarti responden merasa tidak puas akan sikap kepedulian atau keramahan petugas kesehatan saat melayani pasien.

Dari 33 responden yang empati dalam pelayanan kesehatan nya tidak baik, mayoritas responden menjawab puas sebanyak 17 orang $(51,5 \%)$ dan minoritas responden menjawab tidak puas sebanyak 16 orang (48,5\%). Artinya empati atau pemberian perhatian dalam pelayanan kesehatan tidak terlalu berpengaruh karena pemberian perhatian termasuk sikap individual tersendiri yang diberikan petugas kesehatan kepada pasien.

Hal ini menguatkan teori Parasuraman Zeithml (1998), empati merupakan perhatian secara individual yang diberikan tenaga kesehatan terhadap pasien meliputi kemampuan untuk berkomunikasi, perhatian dari petugas kesehatan, kesempatan waktu lebih untuk pasien berkonsultasi kepada tenaga kesehatan(20).

Pengaruh Jaminan dengan Mutu Pelayanan Kesehatan di Puskesmas Rantang Medan Petisah Tahun 2019
Berdasarkan Uji Chi-Square diperoleh nilai $p$ value $=0,804(p$ value $>0,05)$, artinya Ho diterima dan $\mathrm{Ha}$ ditolak, yang artinya tidak ada pengaruh yang signifikan antara jaminan dengan mutu pelayanan kesehatan di Puskesmas Rantang Medan Petisah Tahun 2019.

Hal ini sejalan dengan penelitian di Kabupaten Sragen, dengan judul Pengaruh Mutu Pelayanan Kesehatan dengan Tingkat Kepuasan Pasien Rawat Jalan Peserta Jaminan Kesehatan Nasional di Wilayah Kerja Puskesmas Ngrampel. Dari 100 responden diperoleh nilai $p$-value $=0,701$ nilai $p>$ 0,05 . Maka Ho diterima dan Ha ditolak, artinya jaminan tidak berpengaruh positif dan signifikan terhadap kepuasan pasien (17).

Menurut asumsi peneliti diketahui bahwa dari 43 responden yang jaminan dalam pelayanan kesehatan nya baik, mayoritas responden menjawab tidak puas sebanyak 23 orang 53,5\%) dan minoritas responden menjawab puas sebanyak 20 orang $(46,5 \%)$. Hal ini berarti responden tidak puas akan jaminan pelayanan yang diberikan puskesmas.

Dari 18 responden yang jaminan dalam pelayanan kesehatan nya tidak baik, responden menjawab puas sebanyak 9 orang $(50,0 \%)$ dan responden menjawab tidak puas sebanyak 9 orang $(50,0 \%)$. Artinya responden beranggapan bahwa yang terpenting adalah ketepatan dan keakuratan dalam pemberian pelayanan kesehatan, sehingga itu menjadikan anggapan responden bahwa dalam memberikan jaminan pelayanan kesehatan terhadap masyarakat harus selalu baik.

$\mathrm{Hal}$ ini menguatkan teori Parasuraman Zeithml (1998), jaminan merupakan kemampuan petugas kesehatan atas pengetahuan yang 
sesuai dengan profesi meliputi keterampilan petugas kesehatan(20).

\section{KESIMPULAN}

1. Ada pengaruh bukti fisik (tangible) yang signifikan terhadap mutu pelayanan kesehatan $(p=0,015)$.

2. Ada pengaruh kehandalan (reliability) yang signifikan terhadap mutu pelayanan kesehatan $(p=$ 0,000).

3. Ada pengaruh daya tanggap (responsiveness) yang signifikan terhadap mutu pelayanan kesehatan $(p=0,001)$.

\section{DAFTAR PUSTAKA}

Undang-Undang Republik Indonesia Nomor 36 Tahun 2009 Tentang Kesehatan. In.

Keputusan Menteri Kesehatan Republik Indonesia No 279. Pedoman Penyelenggaraan Upaya Keperawatan Kesehatan Masyarakat Di Puskesmas Menteri Kesehatan Republik Indonesia. In 2016.

Indonesia Service Dialog (ISD). 2018; Diambil dari: jogja.tribunnews.com/amp/2018 /05/10/

The Legatum Prosperity Index. In 2017.

WHO. Measure your blood pressure, reduce your risk. In Geneva: World Health Organization; 2013.

RISKESDAS. Hipertensi/Tekanan Darah Tinggi. In 2018.

Dinas Kesehatan Kota Medan. Profil Kesehatan Kota Medan. In 2016.

Pohan IS. Jaminan Mutu Pelayanan Kesehatan. Jakarta: Buku Kedokteran EGC; 2007.

Azhrul A. Mutu Pelayanan Kesehatan \& Kebidanan. 1996.

Profil Puskesmas Rantang Medan Petisah Tahun 2017. Manajemen Dan Data Pegawai.

Astawa. Faktor - Faktor yang Mempengaruhi Mutu Pelayanan Kesehatan di Puskesmas Rumbia. 2012;

Profil Puskesmas Rantang Medan
Petisah. Data Kunjungan Pasien Penderita Hipertensi Tahun 2015. In 2018.

Profil Puskesmas Rantang Medan Petisah. Data Kunjungan Pasien Penderita Hipertensi Tahun 2016. In 2018.

14. Profil Puskesmas Rantang Medan Petisah. Data Kunjungan Pasien Penderita Hipertensi Tahun 2017. In 2018.

Notoatmodjo S. Metodologi Penelitian Kesehatan. Jakarta: Rineka Cipta; 2012.

Sugiyono. Metode Penelitian Kuantitatif, Kualitatif dan R\&D. Jakarta: Penerbit Alfabeta; 2017.

Lidiana EH. Pengaruh Mutu Pelayanan Kesehatan dengan Tingkat Kepuasan Pasien Rawat Jalan Peserta Jaminan Kesehatan Nasional di Wilayah Kerja Puskesmas Ngrampel. Surakarta; 2017.

Supartiningsih S. Kualitas Pelayanan Kepuasan Pasien Rumah Sakit Sarila Husada. 2017.

Suzanto B. PENGARUH KUALITAS JASA PELAYANAN TERHADAP KEPUASAN PASIEN PADA RUMAH SAKIT UMUM KOTA BANJAR. J Ekon Bisnis Entrep. 2011;5(1):28-44.

Parasuraman, Zeithaml VA, Berry LL. SERVQUAL: A Multiple- item scale for Measuring Consumer Perceptions of Service Quality. 1998. 